Canadian Journal of Bioethics

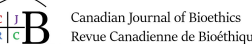

Revue canadienne de bioéthique

\title{
Review of: Austin, W. et al. (2013) Lying Down in the Ever-Falling Snow: Canadian Health Professionals' Experience of Compassion Fatigue
}

\author{
Nipa Chauhan
}

Volume 1, Number 2, 2018

URI: https://id.erudit.org/iderudit/1058285ar

DOI: https://doi.org/10.7202/1058285ar

See table of contents

Publisher(s)

Programmes de bioéthique, École de santé publique de l'Université de Montréal

ISSN

2561-4665 (digital)

Explore this journal

Cite this review

Chauhan, N. (2018). Review of [Review of: Austin, W. et al. (2013) Lying Down in the Ever-Falling Snow: Canadian Health Professionals' Experience of Compassion Fatigue]. Canadian Journal of Bioethics / Revue canadienne de bioéthique, 1(2), 80-80. https://doi.org/10.7202/1058285ar 


\title{
Review of: Austin, W. et al. (2013) Lying Down in the Ever-Falling Snow: Canadian Health \\ En collaboration avec / In collaboration with Professionals' Experience of Compassion Fatigue
}

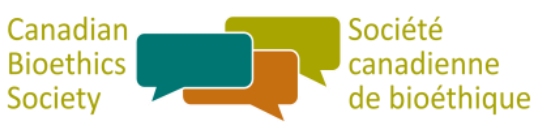

\author{
Nipa Chauhan ${ }^{1}$
}

\section{Mots clés}

Keywords

usure de compassion, soins de santé, professionnel de la santé, compassion fatigue, healthcare, health professional, Canada Canada

Published in 2013, Lying Down in the Ever-Falling Snow by Wendy Austin et al. [1] is a compilation of essays written by various Canadian healthcare professionals about their experiences managing compassion fatigue. Utilizing the Canadian metaphor of endless winter as their guide, the authors contribute to the concept of compassion fatigue by providing anecdotes that can potentially uncover a more focused definition of it. The order in which the book is laid out is practical in that it exhibits an emotional strategy - the book becomes increasingly emotional/sentimental/distressing as the chapters progress. After the philosophical concept of human compassion is introduced and explored, the authors explain how they chose to approach such an emotional experience through hermeneutic phenomenological research; they gather four essays that illustrate how compassion fatigue affects the body, time, space, and relations. After the intimate anecdotes from healthcare professionals are told, the book moves on to texts that are meant to evoke hope and survival, which they believe are the most logical and emotionally important steps to take when one finds oneself directly affected by compassion fatigue. In this work, the authors successfully illustrate their experiences with compassion fatigue as it affects the body, time, space, and relations, while contributing to the research of understanding the concept itself.

Breaking down compassion fatigue's effects into four simple relational concepts proved to be a huge advantage in understanding the crippling nature of such an experience. Starting with the body, "The Cold Heart" chapter describes the numbing effect that healthcare workers may experience and an alarming feeling of self-awareness that commonly follows. The next chapter, "The Endless Winter", describes the seemingly never ending temporal experience of compassion fatigue, further tiring the healthcare worker as they attempt their routines. The chapter entitled "Lost and Alone in a Prairie Blizzard" describes the space in which the health worker finds themself as the workplace becomes a source of dread and extreme stress. With more illustrative and emotional anecdotes, the chapter "An Icy Wall (Within and Between)"' is where the authors share how relationships between clinicians and their patients develop despite the experiences of each party. Small interactions, like running into patients in grocery stores, proves to have much more of an impact on clinicians than they are comfortable with. Trying to answer questions that clinicians do not necessarily have answers to can be quite an exhausting routine.

It is recommended to read this book in installments, as the content within the book may elicit a lesser but significant response of compassion fatigue for the reader. The experiences told within the book are heart-wrenching, but they meet the goal of helping the reader understand how and why clinicians experience such weariness and why compassion fatigue needs to be attended to more fully in the healthcare setting.

Conflit d'intérêts

Aucun déclaré

Édition/Editors: Christy Simpson \& Patrick Gogognon

\section{Affiliations}

${ }^{1}$ Joint Centre for Bioethics, University of Toronto, Toronto, Canada

Correspondance / Correspondence: Nipa Chauhan, nipachauhan@gmail.com
Conflicts of Interest

None to declare

\section{Reçu/Received: 9 Oct $2018 \quad$ Publié/Published: 25 Oct 2018 (BS/SCB: Mar 2018)}

\begin{abstract}
Les éditeurs suivront les recommandations et les procédures décrites The editors follow the recommendations and procedures outlined dans le Code of Conduct and Best Practice Guidelines for Journal in the COPE Code of Conduct and Best Practice Guidelines for Editors de COPE. Plus précisément, ils travaillent pour s'assurer des Journal Editors. Specifically, the editors will work to ensure the plus hautes normes éthiques de la publication, y compris highest ethical standards of publication, including: the identification l'identification et la gestion des conflits d'intérêts (pour les éditeurs et and management of conflicts of interest (for editors and for pour les auteurs), la juste évaluation des manuscrits et la publication authors), the fair evaluation of manuscripts, and the publication of de manuscrits qui répondent aux normes d'excellence de la revue.

manuscripts that meet the journal's standards of excellence.
\end{abstract}

\section{References}

1. Austin W, Brintnell SE, Goble E, Kagan L, Kreitzer L, Larsen D, Leier B. Lying Down in the Ever-Falling Snow: Canadian Health Professionals' Experience of Compassion Fatigue. Waterloo: Wilfrid Laurier University Press, 2013. 